\title{
The subterranean fauna of a biodiversity hotspot region - Portugal: an overview and its conservation
}

\author{
Ana Sofia P.S. Reboleira ${ }^{1,2, *}$, Paulo A.V. Borges ${ }^{3}$, Fernando Gonçalves ${ }^{1}$, Artur R.M. \\ Serrano $^{4} \&$ Pedro Oromí ${ }^{2}$
}

\begin{abstract}
:
Reboleira A.S.P.S., Borges P.A.V., Gonçalves F., Serrano A.R.M., Oromi P. 2011. The subterranean fauna of a biodiversity hotspot region - Portugal: an overview and its conservation. International Journal of Speleology, 40 (1), 23-37. Tampa, FL (USA). ISSN 0392-6672. DOI: 10.5038/1827-806X.40.1.4

An overview of the obligate hypogean fauna in Portugal (including Azores and Madeira archipelagos) is provided, with a list of obligated cave-dwelling species and subspecies, and a general perspective about its conservation. All the available literature on subterranean Biology of Portugal since the first written record in 1870 until today has been revised. A total of 43 troglobiont and 67 stygobiont species and subspecies from 12 orders have been described so far in these areas, included in the so-called Mediterranean hotspot of biodiversity. The subterranean fauna in Portugal has been considered moderately poor with some endemic relicts and it remains to be demonstrated if this fact is still true after investing in standard surveys in cave environments. The major problems related to the conservation of cave fauna are discussed, but it is clear that the protection of this specialized fauna implies an adequate management of surface habitats.
\end{abstract}

Keywords: Biospeleology, hypogean fauna, patterns of diversity, conservation, caves, karst, lava tubes, Portugal, Azores, Madeira

Received 29 June 2010; Revised 5 October 2010; Accepted 21 October 2010

\section{INTRODUCTION}

Extensive biological studies have been made in the main karst areas around the world, namely in the eastern United States of America and in the region from the Pyrenees to Slovenia and the Dinaric karst (Culver et al., 2000; Culver \& Pipan, 2009).

Information about subterranean fauna in mainland Portugal is sparse and scattered along many publications mostly from the middle of the 20th century. The main thrust in the subterranean biology was given by the survey of caves made by Barros Machado during the 1940s, and by the prospection of well-dwelling crustaceans in the north of the country by researchers of the former Instituto de Zoologia "Dr. Augusto Nobre" from Porto University (Gama \& Afonso, 1994). In addition, endogean habitats have been subject of considerable coleopterological

${ }^{1}$ CESAM - Centro de Estudos do Ambiente e do Mar \& Departamento de Biologia, Universidade de Aveiro, Aveiro, Portugal

${ }^{2}$ Departamento de Biología Animal, Universidad de La Laguna, La Laguna, Spain;

${ }^{3}$ Departamento de Ciências Agrárias - CITAA (Azorean Biodiversity Group), Universidade dos Açores, Angra do Heroísmo, Terceira, Açores, Portugal

${ }^{4}$ Faculdade de Ciências da Universidade de Lisboa, Departamento Biologia Animal/Centro de Biologia Ambiental, Lisboa, Portugal.

*Corresponding author. Email: sreboleira@ua.pt exploration in the last decade by Serrano \& Aguiar (see 2008a, 2008b and works cited therein).

Particularly in the Azores, the 1990's were a very productive decade with several biospeological expeditions to study the volcanic cave fauna covering most of the nine islands (e.g., Oromí et al., 1990; Oromí \& Borges, 1991; Borges, 1993; Borges \& Oromí, 1994; Borges et al., 2004, 2007, 2008) and the discovery of at least 19 new obligate hypogean taxa. In the last years an intensive survey of cave fauna has been carried out in all the islands in search of ground-beetle fauna (Amorim, 2005). In Madeira archipelago, the studies of the volcanic cave fauna received also a particular attention in the last years with an exhaustive biodiversity study of lava tubes (Nunes, 2005).

Caves harbor a very specialized fauna and are unique evolutionary laboratories for the study of adaptation and natural selection (Howarth, 1983; Culver \& Pipan, 2009). Subterranean habitats (SH) are characterized by abiotic factors crucial to their biocoenoses, being the most limiting ones the absence of light, the low amount of food resources and the high levels of humidity (Culver \& Pipan, 2009). Several ecological classifications have been proposed to categorize the subterranean fauna based on morpho-physiological adaptations (Sket, 2008). In the present paper, we use the term troglobiont or obligate hypogean species for the species that display 
troglobiomorphisms (sensu Christiansen 2005), such as integument depigmentation, absence or reduced ocular structures and exclusive presence in the SH. The word stygobiont is used for obligate hypogean aquatic animals.

The same adaptations that make the obligate hypogean fauna able to successfully colonize the subterranean environment also decrease their fitness of survival in case of sudden changes in their habitat, especially those related to human activities (Sket, 1999). Likewise, reduction of habitat areas as a result, for instance, of limestone quarries will lead to their extinction. In fact, caves, as islands, are isolated entities and as a consequence, they lack the "rescue effect": only "source" species can be maintained in ecological and evolutionary time (Rosenzweig, 1995). In the Azores, Borges et al. (2008) concluded that there is an urgent need to set rank priorities for conservation, since the resources are not enough to protect all caves in the region.

Several types of subterranean habitats are known in mainland Portugal, but until today the subject of biological studies have been mostly the caves and the freshwater aquifers. The biodiversity in karst and non-karst areas, as well as in the so called "milieu souterrain superficiel” (MSS) (Juberthie et al., 1980a, 1980b) (or mesovoid shallow substratum sensu Culver, 2001) and in the anchialine caves still remain to be unraveled.

According to Bellés (1987) the terrestrial obligate hypogean fauna in mainland Portugal is included in two subterranean biogeographic districts: the Lusitanic which covers most of Portugal, and the Baetic which mainly extends through Spanish Andalusia but also includes the Portuguese Algarve to the west. Some considerations about the biogeography of hypothetical troglobionts in the north of Portugal were made by Jeannel, relating them to the GalaicoCantabrian area (Jeannel, 1941). The terrestrial subterranean fauna of the Portuguese archipelagos belongs to the biogeographic area called Macaronesia. Taking into consideration that mainland Portugal and the archipelagos of the Azores and Madeira are included in the so-called Mediterranean Hotspot of Biodiversity, there is some urgency to know in detail the real diversity of subterranean organisms in order to improve their conservation management (Myers et al., 2000). The main goals of this work are: i) to list for the first time all the species and subspecies of obligate hypogean fauna of Portugal, including the archipelagos of Madeira and Azores; ii) to discuss the conservation vulnerabilities of this specialized fauna in the studied regions.

\section{MATERIAL AND METHODS \\ Region of study}

Portugal is the southwesternmost country of Europe, located in the western part of the Iberian Peninsula and including two volcanic archipelagos (Madeira and Azores). The Portuguese territory has a total area of $92,090 \mathrm{~km}^{2}$ and borders with Spain to the north and east, and to the south and west with the Atlantic Ocean, where the two archipelagos are located (Figure 1).

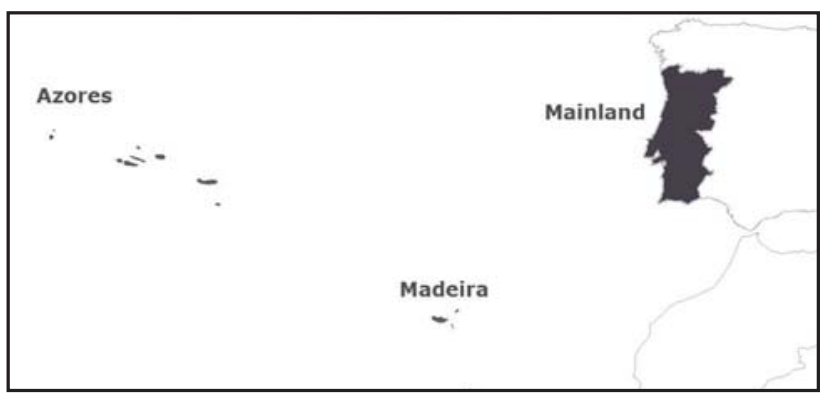

Fig. 1. Location of Portugal, mainland and archipelagos.

Since the archipelagos are of volcanic origin and have almost no carbonate rocks, all karst areas are found in the mainland (Figure 2). Several caves are included in ten protected areas of different status, such as parks, protected landscapes and classified sites. Anyway, all caves are public domain according to the Article 84 of the Portuguese Constitution [1. Belong to the public domain: c) the natural underground cavities].



Fig. 2. Major karst areas of Portugal. 1 - Dine; 2 - Vimioso; 3 - Cantanhede; 4 - Mealhada; 5 - Boa Viagem; 6 - Sicó-Condeixa e Alvaiázere;

7 - Estremenho; 8 - Cesaredas; 9 - Montejunto; 10 - Península de Lisboa; 11 -Arrábida; 12 - Estremoz-Cano; 13 -Adiça-Ficalho; 14 -Algarve. 
The most important karst areas are Jurassic limestones and dolomites: Estremenho (Serra d'Aire e Candeeiros), Arrábida, Sicó-Condeixa-Alvaiázere, Montejunto, and Algarve; but there are also caves present in Cambrian limestones and marbles in Estremoz and Adiça in the Alentejo, and in Vimioso on the northeast region (Brilha et al. 2005). Caves are found from the sea level in Arrábida, Boa Viagem and Algarve up to the higher karst point at $667 \mathrm{~m}$ in Serra do Montejunto (Machado \& Machado, 1948). The air temperature of caves ranges from $11^{\circ} \mathrm{C}$ to 21 ${ }^{\circ} \mathrm{C}$ (pers. obs.).

In the archipelagos of Azores and Madeira the terrain is mainly volcanic, with the exception of thin layers of limestone of coastal reef origin in Madeira, Ilhéu da Cal and Azores, Santa Maria (Ávila et al., 2008). The volcanic origin of the archipelagos implies that subterranean habitats are rather different than those in mainland karst areas, but also inhabited by an adapted and highly endemic fauna, especially in the Azores (Oromi et al., 1990; Borges, 1993; Borges \& Oromí, 1994; Nunes, 2005). The abundant caves on these islands are mostly lava tubes and volcanic pits (Oromí et al., 1990; Nunes, 2005; Pereira et al., in press) but the particular MSS of volcanic areas has also provided obligate hypogean species (Borges, 1993), though much is still to be done concerning the sampling of this environment.

\section{Data}

The entire bibliography on Portuguese hypogean biology has been revised (not including references to Chiroptera). Among the different degrees of adaptation to subterranean life that can be found, for the present paper, we only consider as obligate hypogean fauna (also called troglobiont) those species with exclusive presence in subterranean habitats, which clearly show at least one of the following characters: integument depigmentation, absence or at least clear reduction of eyes, slender and long body and appendages, and wings absent or rudimentary (for insects).

In Portuguese the term cave has different names according to their morphology and regionalism: 'lapa, cova, fojo, furna, gruta or lorga' for small horizontal caves, ‘algar, algarve, algarão or algueirão' for vertical caves and 'gruta' or 'furna' for horizontal caves.

\section{RESULTS}

A total of 110 species and subspecies from 12 orders have been listed here as obligate hypogean fauna living in caves, MSS and groundwaters of Portugal. Among them, 43 are troglobionts and 67 are stygobionts.

The majority of the obligate hypogean fauna is very often restricted to one or few caves. In the mainland, the species are usually endemic to one karst massif or part of it, and in the archipelagos most of the species are single island endemisms (SIEs) (Borges et al., 2008).

Most of the stygobionts were found in wells in nonkarst areas with the exception of Syncarida, obtained by the Karaman-Chappuis method (Camacho, 2003a; 2003b) and the Amphipoda from Madeira archipelago collected with the Bou-Rouch biophreatical pump (Stock \& Abreu, 1992; Stock, 1992).

The subterranean species of Portugal are listed below, by taxonomic group, for mainland and islands, with their localities. For the Azores, the list of species with a detailed $500 \times 500$ grid distribution is available in the Azorean Biodiversity Portal (http://www. azoresbioportal.angra.uac.pt) (Borges et al., 2005; in press).

\section{Oligochaeta (1) \\ Mainland (1)}

Tubificidae. Rhyacodrilus lindbergi Hrabe, 1963 Estremenho: Gruta das Alcobertas, Rio Maior, also recorded in caves in France (Giani et al., 2001).

\section{Palpigradi (1) \\ Islands (1)}

Eukoeneniidae. Eukoenenia madeirae Strinati \& Condé, 1995 - Madeira: Gruta de Cavalum I and II, Machico (Nunes, 2005).

\section{Pseudoscorpiones (5) Mainland (2)}

Neobisiidae. Roncocreagris blothroides (Beier, 1962) (=Microcreagris blothroides Beier, 1962) - Sicó: Cova da Moura, Condeixa (Zaragoza, 2007). Roncocreagris cavernicola (Vachon, 1946) (= Microcreagris cavernicola Vachon, 1946) - Sicó: Algar Sul das Corujeiras, Algar da Lapa, Ansião, Pombal (Zaragoza, 2007).

\section{Islands (3)}

Chthoniidae. Paraliochthonius cavalensis Zaragoza, 2004 - Madeira: Gruta do Cavalum III, Machico (Zaragoza et al., 2004; Nunes, 2005).

Syarinidae. Pseudoblothrus oromii Mahnert, 1990 Azores, São Jorge: Gruta da Beira (Pereira et al., in press).

Pseudoblothrus vulcanus Mahnert, 1990 - Azores, Terceira: Gruta das Agulhas, Gruta do Coelho, Gruta da Malha, Gruta dos Principiantes, and Pico: Furna da Baliza, Furna Frei Matias, Furna Nova I (Pereira et al., in press).

\section{Opiliones (1) \\ Mainland (1)}

Sironidae. Iberosiro dyctilus Bivort \& Giribet, 2004 - Montejunto: Algarve da Terra da Rolha, Cadaval (Bivort \& Giribet, 2004).

\section{Araneae (8) \\ Mainland (4)}

Leptonetidae. Teloleptoneta synthetica (Machado, 1951) - Arrábida: Cova do médico, Sesimbra; Adiça: Cova da Adiça, Moura; and Algarve: Algueirão do Garrafão, Algarinhos, Loulé; Algueirão dos Mouros, Moncarapacho; Abismo Novo, Moncarapacho, Olhão; Algarinhos de Benafim, Alte (Ribera, pers. com.; Ribera, 1988).

Dysderidae. Harpactea stalitoides Ribera, 1993 Algarve: Algarão menor do Paulino, Algarão dos mouros, Gruta do Vale Telheiro, Loulé and Gruta da Senhora, Moncarapacho (Reboleira, pers. obs.; Ribera, 1993). 
Symphytognathidae. Anapistula ataecina Cardoso \& Scharff, 2009 - Arrábida: Gruta do Fumo, Lapa da Furada, Gruta da Utopia, Sesimbra (Cardoso \& Scharff, 2009).

Nesticidae. Nesticus lusitanicus Fage, 1931 Estremenho: this species is in the entire massif and is observed from areas near the caves entrance to a depth of 150 meters (Reboleira, 2007).

\section{Islands (4)}

Theridiidae. Rugathodes pico (Merrett \& Ashmole, 1989) - Azores, Pico: Gruta das Canárias, Furna dos Montanheiros, Gruta da Agostinha, Gruta do Henrique Maciel, Gruta do Mistério da Silveira I, Gruta do Soldão; and Faial: Furna Ruim (Pereira et al., in press).

Linyphiidae. Turinyphia cavernicola Wunderlich, 2005 - Azores, Terceira: Algar do Carvão (Borges \& Wunderlich, 2008) and Gruta da Malha (Pereira et al., in press). Centromerus anoculus Wunderlich, 1995 Madeira: Gruta dos Cardais, São Vicente (Wunderlich, 1995). Centromerus sexoculatus Wunderlich, 1992 Madeira: Furnas de Cavalum, Machico (Wunderlich, 1992).

\section{Chilopoda (2) \\ Mainland (1)}

Lithobidae. Lithobius dimorphus Machado, 1946 - Algarve: Algarão do Barrocal do Esguicho, Loulé, Algarão menor do Paulino, Cerro da Cabeça Gorda (Machado, 1946).

\section{Islands (1)}

Lithobidae. Lithobius obscurus azoreae Eason \& Ashmole, 1992 - Azores, Faial, Pico, Graciosa, Terceira: in many caves (Pereira et al., in press).

\section{Syncarida (8) \\ Mainland (8)}

Parabathynellidae. Iberobathynella barcelensis (Noodt \& Galhano, 1969) - Gravel bank in Cávado River, Barcelos. Iberobatynella cavadoensis (Noodt and Galhano, 1969) - Gravel bank in Cávado River, Barcelos, also recorded in Spain (Camacho, 2003 a). Iberobatynella gracilipes (Braga, 1960b) - Gravel bank in Idanha-a-Nova. Iberobatynella lusitanica (Braga, 1949) - Gravel bank in Leça da Palmeira. Iberobatynella pedroi Camacho, 2003 - Gravel bank on the River Mondego in Coimbra (Camacho, 2003a). Iberobatynella serbani Camacho, 2003 - Gravel bank on the Lima River, in Ponte de Lima (Camacho, 2003a). Iberobatynella valbonensis (Galhano, 1970) - Gravel bank in Gondomar, also recorded in Spain (Camacho, 2003a). Hexabathynella minuta Noodt \& Galhano, 1969 - Gravel bank in Zebreiros, Douro River (Camacho, 2003b).

\section{Amphipoda (11) \\ Mainland (6)}

Bogidiellidae. Bogidiella helenai Mateus \& Maciel, 1967 - In brackish water, Foz do Douro (Mateus \& Mateus, 1978; Notenboom, 1990) .

Niphargidae. Haploginglymus bragai Mateus \& Mateus 1958 - Leça da Palmeira, also in Spain
(Mateus \& Mateus, 1978; Notenboom, 1990).

Melitidae. Pseudoniphargus callaicus Notenboom, 1987 - North Atlantic coast of Portugal, also recorded in the Northwest of Spain (Notenboom, 1990). Pseudoniphargus longispinum Stock, 1980 - Mainland Portugal (Notenboom, 1990). Pseudoniphargus mateusorum Stock, 1980 - Arrábida: Fojo dos Morcegos, Sesimbra (Notenboom, 1990).

Hadziidae. Metahadzia tavaresi (Mateus \& Mateus, 1972) - Algarve (Notenboom, 1990).

\section{Islands (5)}

Melitidae. Pseudoniphargus brevipedunculatus Stock, 1990 - Azores, Faial (Sánchez, 1990). Pseudoniphargus litoralis Stock \& Abreu, 1992 Madeira: São Roque spring, Machico (Stock \& Abreu, 1992). Pseudoniphargus macrurus Stock \& Abreu, 1992 - Madeira: south of Porto Moniz, Ribeira Brava and Ribeira da Janela (phreatic pump in gravel) (Stock \& Abreu, 1992). Pseudoniphargus portosancti Stock \& Abreu, 1992 - Madeira, Porto Santo: spring of Tanque and fountain of Baião (Stock \& Abreu, 1992).

Ingolfiellidae. Ingolfiella ungiculata Stock, 1992 - Lugar de Baixo, anchialine pool, Madeira (Stock, 1992).

\section{Isopoda (55) \\ Mainland (54)}

Asellidae. Bragasellus conimbricensis (Braga, 1946) - Coimbra. Bragasellus frontellum (Braga, 1964) Ponte da Barca, Vila do Conde, Minho (Afonso, 1987b). Bragasellus incurvatus Afonso, 1984 -Figueira de Castelo Rodrigo and Pinhel, Beira-Alta (Afonso, 1984b). Bragasellus pauloae (Braga, 1958) - Idanhaa-Nova. Bragasellus seabrai (Braga, 1943) - Leça da Palmeira, Matosinhos. Proasellus arthrodilus (Braga, 1945) - Sicó: Gruta de Legacão, Ansião (Afonso, 1983). Proasellus assaforensis Afonso, 1988 - Península de Lisboa: Gruta da Assafora, Sintra (Afonso,1983). Proasellus exiguus Afonso, 1983 - Viseu, Serra da Lapa. Proasellus lusitanicus (Frade, 1938) - Estremenho: dark pit of Alviela, Alcanena, Gruta da Contenda, Gruta do Mindinho and Gruta dos Moinhos Velhos, Mira d'Aire (Afonso, 1983; Magniez, 1966). Proasellus mateusorum Afonso, 1982 - Vendas Novas, Évora (Afonso, 1982c). Proasellus rectangulatus Afonso, 1982 - Montemor-o-Novo, Alentejo (Afonso, 1982a). Proasellus rectus Afonso, 1982 - Horta dos Moinhos, Évora (Afonso, 1982b). Proasellus spinipes Afonso, 1979 - Estremenho: Algar do Ladoeiro, Porto de Mós (Afonso, 1979). Proasellus nobrei Braga, 1942 - Foz do Douro (Braga, 1942b). Psammasellus capitatus Braga, 1968 - Alluvial phreatic in Douro River, Entreos-Rios. Stenasellus galhanoae Braga, 1962 - Algarve: Tavira, São Brás de Alportel, Lagos, Tavira (Braga, 1962; Magniez, 1999). Stenasellus virei nobrei Braga, 1942 - Dark pit in Foz do Douro and Freixo de Numão, Guarda (Braga, 1942b; Magniez, 1999). Synasellus albicastrensis Braga, 1960 - Castelo Branco, BeiraBaixa. Synasellus barcelensis Noodt \& Galhano, 1969 - Cávado river (Noodt \& Galhano, 1969). Synasellus bragai Afonso, 1987 - Minho, São Pedro da Torre (Afonso, 1987a). Synasellus brigantinus Braga, 1959 - 
Bragança (Afonso, 1992). Synasellus capitatus (Braga, 1968) - Porto. Synasellus exiguus Braga, 1944 Douro River, Vila da Parede (Braga, 1944). Synasellus dissimilis Afonso, 1987 - Serzedelo, Amêdos (Afonso, 1987b). Synasellus favaiensis Eiras, 1974 - Douro River (Eiras, 1974). Synasellus flaviensis Afonso, 1996. Synasellus fragilis (Braga, 1946) - Valbom, Porto. Synasellus henrii Afonso, 1987 - Póvoa do Lanhoso (Afonso, 1987b). Synasellus insignis Afonso, 1984 - Aguda, Miramar (Afonso, 1984a). Synasellus intermedius Afonso, 1985 - Vila Franca das Naves, Douro (Afonso, 1985). Synasellus lafonensis Braga, 1959 - Vouga River, São Pedro do Sul (Afonso, 1992). Synasellus longicauda Braga, 1959 - Meda, BeiraAlta (Braga, 1959). Synasellus longicornis Afonso, 1978 - Sabugal (Afonso, 1978). Synasellus mariae (Braga, 1942) - Leça da Palmeira, Minho (Braga, 1942a; Afonso, 1992). Synasellus mateusi Braga, 1954 - Vila Real, Trás-os-Montes (Afonso, 1992). Synasellus meirelesi Braga, 1959 - Idanha-a-Nova, Beira-Baixa (Braga, 1959). Synasellus minutus Braga, 1959 - Curia, Coimbra. Synasellus nobrei Braga, 1967 - Entre-os-Rios, Douro (Braga, 1967). Synasellus pireslimai Braga, 1959 - Vouga River, Gouveia, BeiraAlta (Afonso, 1992). Synasellus pombalensis Afonso, 1987 - Serra de Sicó, Pombal (Afonso, 1987b). Synasellus robusticornis Afonso, 1987 - Estradinha, Santa Comba Dão (Afonso, 1987b). Synasellus serranus Braga, 1967 - Serra d'Arga, Viana do Castelo (Braga, 1967). Synasellus tirsensis Afonso, 1987 - Vila das Aves, Vizela River (Afonso, 1987b). Synasellus transmontanus Braga, 1954 - Bragança (Afonso, 1992). Synasellus valpacensis Afonso, 1996 - Valpaço (Afonso, 1996). Synasellus vidaguensis Afonso, $1996-$ Douro River (Afonso, 1996). Synasellus vilacondensis Afonso, 1987 - Vila do Conde (Afonso, 1987).

Porcellionidae. Porcellio cavernicolus Vandel, 1945 - Sicó: Gruta dos Alqueves, Coimbra, Algar da Lapa, Ansião (Vandel, 1945).

Trichoniscidae. Trichoniscoides broteroi Vandel, 1945 - Sicó: Gruta dos Alqueves, Coimbra (Vandel, 1945). Trichoniscoides subterraneus Vandel, 1945 Estremenho: Gruta Alta do Cabeço-dos-Mosqueteiros, Fátima (Vandel, 1945). Trichoniscoides meridionalis Vandel, 1945 - Estremenho: Lapa da Chã de Cima, Gruta das Alcobertas, Rio Maior (Vandel, 1945). Trichoniscoides ouremensis Vandel, 1945 Estremenho: Lapa Salgada, Fátima (Vandel, 1945). Trichoniscoides machadoi subterraneus Vandel, 1945 - Algarve: Loulé.

Armadillidiidae (Vandel, 1945). Troglarmadillidium machadoi Vandel, 1945 - Algarve: Algarão Menor do Paulino, Abismo Novo, Loulé, Moncarapacho (Vandel, 1945).

Islands (1)

Trichoniscidae. Trichoniscus bassoti Vandel, 1960 - Madeira: Furnas de Cavalum, also found in the Canary Islands (Dalens, 1984; Oromí, 1992).

\section{Collembola (1)}

Mainland (1)

Onychiuridae. Onychiurus confugiens Gama, 1962
- Estremenho: Gruta das Alcobertas, Rio Maior, Algar do Pena, Alcanena, Gruta das Ventas do Diabo, Mira d'Aire (Gama, 1962).

\section{Homoptera (2) \\ Islands (2)}

Cixidae. Cixius azopicavus Hoch, 1991 - Azores, Pico: in many caves (Pereira et al., in press). Cixius cavazoricus Hoch, 1991 - Azores, Faial: Gruta das Anelares, Gruta do Cabeço do Canto (Hoch, 1991).

\section{Coleoptera (15) \\ Mainland (4)}

Carabidae. Trechus gamae Reboleira \& Serrano, 2009 - Estremenho: Algar de Marradinhas II, Algar de Gralhas VII, Algar do Pena, Alcanena, Algar do Ladoeiro, Algar da Arroteia, Porto de Mós (Reboleira et al., 2009). Trechus lunai Reboleira \& Serrano, 2009 Estremenho: Gruta do Almonda, Torres Novas, Gruta da Contenda, Mira d'Aire (Reboleira et al., 2009). Trechus machadoi Jeannel, 1941 - Estremenho: Gruta de Alcobertas, Rio Maior (Jeannel, 1941).

Leiodidae. Speonemadus angusticollis (Kraatz, 1870) - Algarve: very abundant in caves along the Algarve (Reboleira pers. obs.) (Jeannel, 1941).

\section{Islands (1 1)}

Carabidae. Trechus isabelae Borges \& Serrano, 2007 - Azores, São Jorge: Algar do Morro Pelado (=Montoso) (Borges et al. 2007). Trechus jorgensis Oromí \& Borges, 1991 - Azores, São Jorge: Algar das Bocas do Fogo (Oromí \& Borges, 1991). Trechus montanheirorum Oromi \& Borges, 1991 - Azores, Pico: Gruta dos Vimes, Furna dos Montanheiros, Furna Frei Matias (Oromi \& Borges, 1991). Trechus oromii Borges, Serrano \& Amorim, 2004 - Azores, Faial: Gruta do Parque do Capelo (Borges et al., 2004). Trechus pereirai Borges, Serrano \& Amorim, 2004 Azores, Pico: Gruta da Ribeira do Fundo; Gruta das Cabras II (Borges et al., 2004). Trechus picoensis Machado, 1988 - Azores, Pico: in several caves (Borges et al., 2007). Trechus terceiranus Machado, 1988 - Azores, Terceira: in several caves (Borges et al., 2007). Thalassophilus azoricus Oromí \& Borges, 1991 - Azores, São Miguel: Gruta da Água de Pau (Oromí \& Borges, 1991). Thalassophilus coecus Jeannel, 1938 - Madeira: MSS of laurisilva forest (Oromí \& Borges, 1991). Thalassophilus pieperi Erber, 1990 - Madeira: Furnas de Cavalum and Gruta de Landeiros, Machico, Gruta dos Cardais, São Vicente (Erber,1990; Nunes, 2005).

Staphylinidae. Medon vicentensis Serrano, 1993 Madeira: Gruta dos Cardais, São Vicente (Serrano, 1993).

\section{Patterns of diversity}

\section{DISCUSSION}

In order to analyze subterranean biodiversity in Portugal we must make a distinction between troglobiont (Figure 6, Table 1) and stygobiont (Table 2) fauna, and among the three main biogeographic parts: mainland Portugal, Azores and Madeira. These regions present different lithogeny, species origin, ancestors, biogeographical patterns, distribution and faunal composition. 


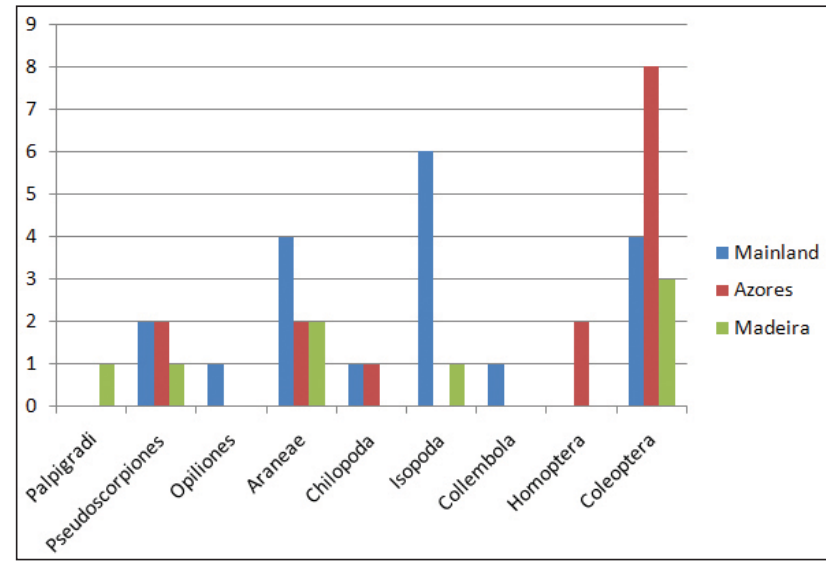

Fig. 6. Number of troglobiont species by taxonomic groups in the mainland and the two archipelagos. Mainland in blue, Azores in red and Madeira in green.

Table 1. Number of troglobiont species and subspecies in Portugal.

\begin{tabular}{|c|c|c|c|c|}
\hline Taxa & Mainland & Azores & Madeira & Total \\
\hline Palpigradi & 0 & 0 & 1 & 1 \\
\hline Pseudoscorpiones & 2 & 2 & 1 & 5 \\
\hline Opiliones & 1 & 0 & 0 & 1 \\
\hline Araneae & 4 & 2 & 2 & 8 \\
\hline Chilopoda & 1 & 1 & 0 & 2 \\
\hline Isopoda & 7 & 0 & 1 & 8 \\
\hline Collembola & 1 & 0 & 0 & 1 \\
\hline Homoptera & 0 & 2 & 0 & 2 \\
\hline Coleoptera & 4 & 8 & 3 & 15 \\
\hline Total & 20 & 15 & 8 & 43 \\
\hline
\end{tabular}

Table 2. Number of stygobiont species and subspecies in Portugal.

\begin{tabular}{|c|c|c|c|c|}
\hline Taxa & Mainland & Azores & Madeira & Total \\
\hline Oligochaeta & 1 & 0 & 0 & 1 \\
\hline Syncarida & 8 & 0 & 0 & 8 \\
\hline Amphipoda & 6 & 1 & 4 & 11 \\
\hline Isopoda & 47 & 0 & 0 & 47 \\
\hline Total & 62 & 1 & 4 & 67 \\
\hline
\end{tabular}

\section{Troglobionts of mainland Portugal}

Fig. 3

All terrestrial obligate hypogean species known from mainland Portugal are endemic to one massif, or to subunits of each karst areas, with the exception of the beetle Speonemadus angusticollis that is also present in subterranean spaces of the centre and south of the Iberian Peninsula (Salgado et al., 2008), and the spider Teloleptoneta synthetica that is found in caves in Arrábida, Alentejo and Algarve.

All Pseudoscorpiones, Opiliones, Isopoda, Collembola and three Araneae are eyeless and display a high degree of troglobiomorphism in opposition to Coleoptera, that are not eyeless but microphtalmous, and do not display a high degree of troglobiomorphism.

Some troglobionts from karst areas have been considered by their authors as relicts, such as Teloleptoneta synthetica, Harpactea stalitoides and Troglarmadillidium machadoi, attesting to their antiquity in the continental Portugal.

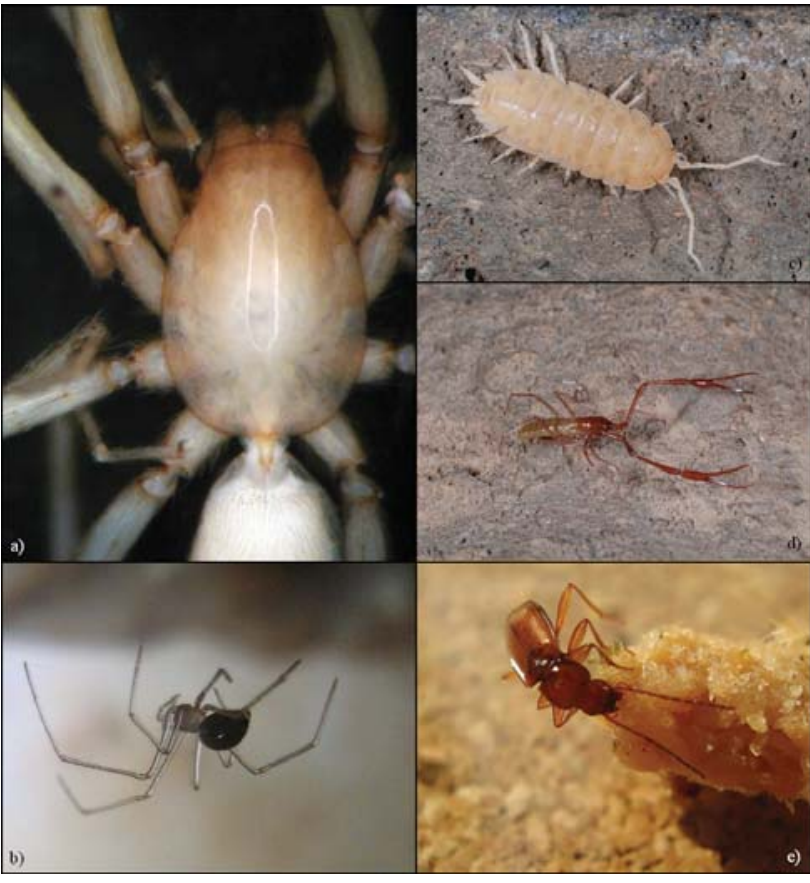

Fig. 3. Troglobionts of mainland Portugal. a) Harpactea stalitoides Ribera, 1993; b) Nesticus lusitanicus Fage, 1931; c) Porcellio cavernicolous Vandel, 1946; d) Roncocreagris blothroides (Beier), 1962 and e) Trechus gamae Reboleira \& Serrano, 2009. (Photos: S. Reboleira and P. Oromí)

An interesting example is the typical allopatric speciation by geographic isolation in the subterranean habitat of the genus Trechus Clairville, 1806 in the Estremenho karst massif, where each geological subunit of this massif has its own cave-dwelling species (Reboleira et al., 2009).

\section{Troglobionts of the Azores}

Fig. 4

The ground-beetle Thalassophilus azoricus, the spider Turinyphia cavernicola and the two pseudoscorpion species of Pseudoblothrus are highly interesting because no congeneric epigean species are known in the archipelago, thus they may be considered as regional relicts. Most notably Pseudoblothrus oromii and Thalassophilus azoricus are known from a single cave each, in São Jorge and São Miguel respectively. In both cases the land above the caves is highly modified due to intensive pastures.

All the Azorean hypogean Trechus species are single island endemics (Borges et al., 2007) and, except in Terceira and São Miguel islands, there are no known epigean species. It could be assumed that they are local relicts, though very recent extinctions due to massive deforestations might also explain this apparent relict condition. These species and particularly the epigean ones are among the rarest Azorean endemic arthropods, since they occur on only one island and in very specific habitats, underneath terrains formerly occupied by native woodlands and now transformed into pastureland.

The Azorean lava tubes frequently have abundant roots hanging inside, allowing the presence of troglobiont planthoppers. One of the most intriguing biogeographical puzzles in the Azorean subterranean 


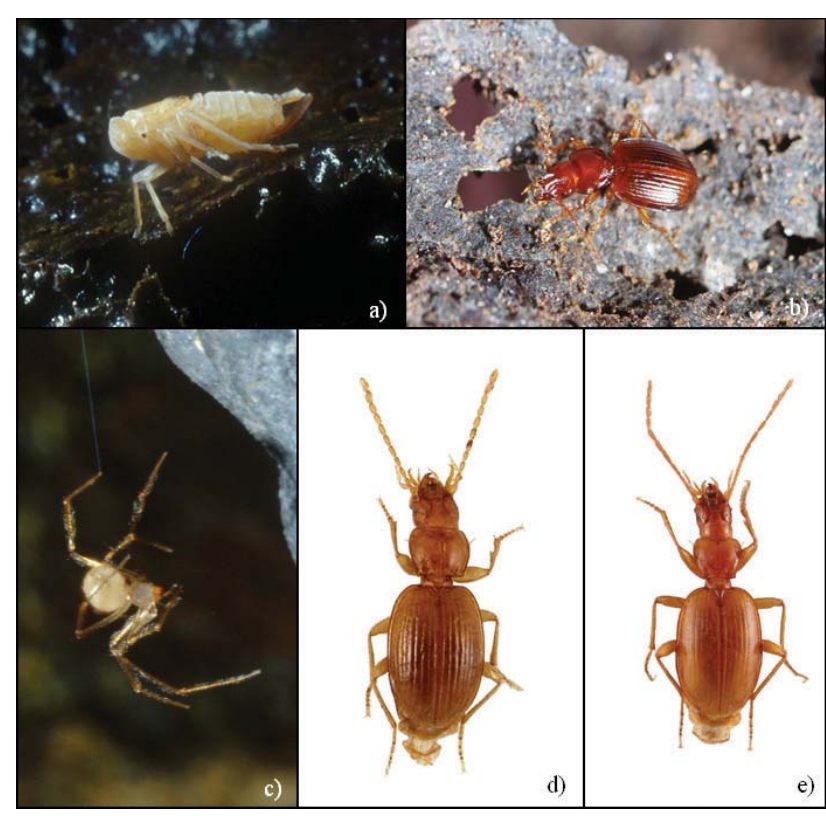

Fig. 4. Troglobionts of Azores. a) Cixius cavazoricus Hoch, 1991; b) Trechus terceiranus Machado, 1988; c) Rugathodes pico (Merrett \& Ashmole, 1989); d) Trechus jorgensis Oromí \& Borges, 1991 and e) Trechus picoensis Machado, 1988. (Photos: P. Oromí and E. Mendonça).

fauna is the register of the same nominal species in two or even more islands; these taxonomical enigmas can be solved after molecular analysis of the populations from different islands.

\section{Troglobionts of Madeira}

Fig. 5

Most of the few Madeiran obligate hypogean species belong to genera with epigean species, which are rather probably their close relatives. All Madeiran troglobionts belong to genera also present in other Macaronesian archipelagos, being represented also by obligate hypogean species such as the pseudoscorpion Paraliochthonius and the coleopterans Thalassophilus and Medon all of them still having reduced eyes. Thalassophilus coecus was described based on a male found under a stone in the humid laurel forest; due to its ocular regression, it has been considered in the present work as a true subterranean species. The spiders Centromerus anoculus, described after a male, and C. sexoculatus, described after a female, have been recently collected, both species and both sexes, in the caves Furnas de Cavalum and are probably the same species, in which case $C$. anoculus would be a junior synonym of $C$. sexoculatus (Ribera, pers. com.). No obligate hypogean species have been found in the MSS, probably due to the absence of studies in such habitat.

\section{Stygobionts}

The stygobiont species so far known from mainland Portugal (Table 2) belong to Oligochaeta, Amphipoda and Isopoda. Several species of Copepoda have also been recorded in subterranean aquifers (LescherMoutoué, 1981), but none of these species are considered as stygobionts.

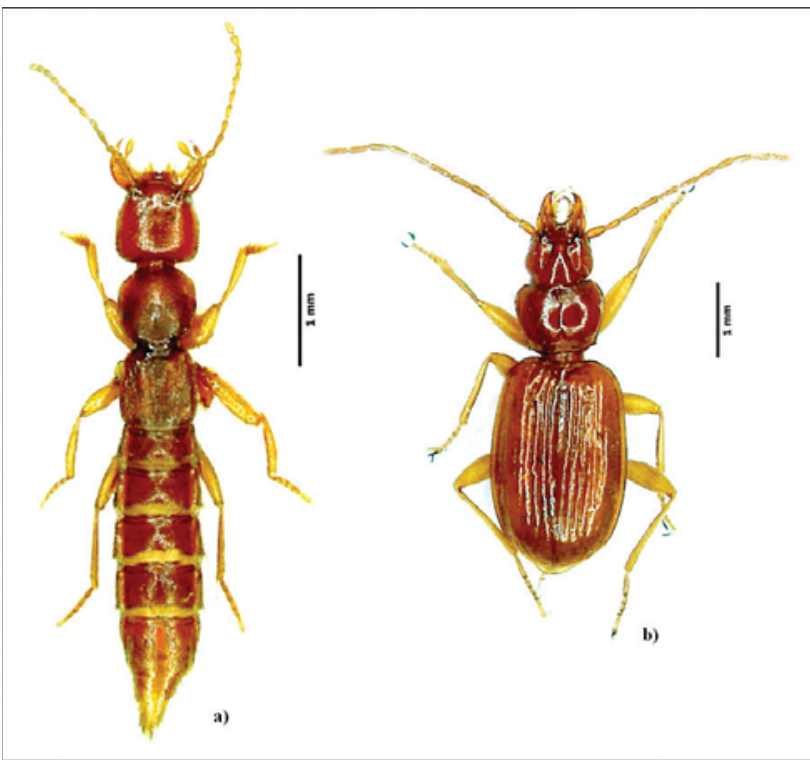

Fig. 5. Troglobionts of Madeira. a) Medon vicentensis Serrano, 1993 and b) Thalassophilus pieperi Erber, 1990. (Photos: E. Mendonça).

The order Isopoda is the most diversified group among stygobionts, being represented by: 5 species of the Iberian endemic genus Bragasellus Henry \& Magniez, 1968; 9 of the perimediterranean genus Proasellus Dudich, 1925; one of the endemic monospecific genus Psammasellus Braga, 1968; 30 of Synasellus Braga, 1944 and one species and subspecies of Stenasellus Dollfus, 1987.

Concerning the amphipods, the genus Haploginglymus Mateus \& Mateus, 1958 is strictly endemic to the Iberian Peninsula, being the most widely distributed stygobiont amphipod (Notenboom, 1990). A curious fact is the absence in Portugal of some Iberian genera of stygobionts, such as Salentinella Ruffo, 1947 frequently found together with Haploginglymus and Niphargus Schiödte, 1849.

The genus Pseudoniphargus Chevreux, 1901 has a disjunct distribution in the Iberian Peninsula with three ranges: northern Spain, southern Spain, and Lusitanic (Notenboom 1990). Their origin in subterranean waters is probably related to a common thalassostygobiont ancestor from the Atlantic and West Mediterranean coasts (Bréhier \& Jaume, 2009). This may explain the presence of Pseudoniphargus near the coast in mainland Portugal and in the Macaronesian archipelagos, where it is the major representative of the insular stygofauna known so far.

Around $90 \%$ of the stygobionts in mainland Portugal are known from non-karst areas of the northern regions. This high percentage may not reflect the real biodiversity but the result of a great prospective effort by the researchers of the Instituto de Zoologia "Dr. Augusto Nobre" of Porto University, during the second half of the 20th century, in those areas.

\section{Conservation}

The main problem on obligate hypogean life conservation is chiefly derived from human pollution produced on the surface, which quickly percolates the superficial layers of limestone, contaminating the 
Table 3. Major threats to conservation and protection in karst areas of Portugal. Legend: Troglobionts interest is based in the proportional number of species by karst area. P, Pollution; Q, Quarries; I, Industry; A, Agriculture; H, Human utilization; T, Touristic caves; V, cave visits; D, degraded, S, Radical modification of surface substratum; CS, Classified Site; PL, Protected Landscape; N2000, Natura 2009;*, part of it.

\begin{tabular}{|c|c|c|c|c|}
\hline Karst area & Province & Troglobionts & Major problems & Protection \\
\hline Dine & Trás-os-Montes & Low & V & Park \\
\hline Vimioso & Trás-os-Montes & Low & $\mathrm{D}$ & None \\
\hline Cantanhede & Beira-Litoral & Medium & $P, A, I, D$ & None \\
\hline Mealhada & Beira-Litoral & Medium & $P, A, I, D$ & None \\
\hline Boa Viagem & Beira-Litoral & Low & $\mathrm{Q}, \mathrm{P}, \mathrm{A}$ & N2000 \\
\hline Sicó & Beira-Litoral & High & $\mathrm{Q}, \mathrm{P}, \mathrm{I}, \mathrm{A}, \mathrm{H}, \mathrm{T}, \mathrm{V}, \mathrm{D}$ & N2000* \\
\hline Estremenho & Estremadura and Ribatejo & High & $\mathrm{Q}, \mathrm{P}, \mathrm{I}, \mathrm{A}, \mathrm{H}, \mathrm{T}, \mathrm{V}, \mathrm{D}$ & Park*, Ramsar* \\
\hline Cesaredas & Estremadura & High & $P, A, D$ & None \\
\hline Montejunto & Estremadura & High & $\mathrm{Q}, \mathrm{P}, \mathrm{A}, \mathrm{V}$ & $\mathrm{PL}^{*}, \mathrm{~N} 2000$ \\
\hline Lisboa & Estremadura & High & $\mathrm{P}, \mathrm{S}, \mathrm{I}, \mathrm{V}, \mathrm{S}$ & None \\
\hline Arrábida & Estremadura & High & $\mathrm{Q}, \mathrm{P}, \mathrm{A}, \mathrm{V}, \mathrm{D}$ & Park, CS \\
\hline Estremoz-Cano & Alto Alentejo & Low & $Q, P, A, D$ & None \\
\hline Adiça-Ficalho & Baixo Alentejo & Low & $A, P$ & None \\
\hline Algarve & Algarve & High & $\mathrm{Q}, \mathrm{P}, \mathrm{A}, \mathrm{H}, \mathrm{V}, \mathrm{D}$ & None \\
\hline
\end{tabular}

subterranean habitats (Watson et al., 1997).

On the other hand, another problem, related to the direct destruction of the subterranean habitat, arises from the economic value of the karst itself (Table 3). Agriculture, industry, freshwater supply, limestone extraction and massive tourism are the most important activities in Portuguese karst areas. In several natural parks, like Serra de Aire e Candeeiros and Arrábida, caves and landscapes are being destroyed by quarrying, which also damages the surface layer inducing deep changes in the way that water, nutrients and pollutants reach the deep parts of the massifs.

Extreme pollution is produced by several industries that are pouring industrial sewage directly into cave systems, as in the case of Gruta de Colaride (Cacém, Lisboa), and by the lack of pervasive treatment of domestic sewage, as it happens in Gruta do Soprador do Carvalho (Sicó). This is a source of outbreaks of microbial infections resulting in public health problems, as it happens in Mira d'Aire (Estremenho).

The soil use on the surface and the hydrologic disturbance may also disrupt obligate hypogean populations. This can also have a natural cause, such as fires that induce deep changes in the vegetation cover, changing the acidification of infiltrating water. Modifications in water $\mathrm{pH}$ may induce deep changes on living subterranean communities, especially on the stygobiont communities (Watson et al., 1997).

For example, in Gruta de Alvide (Cascais, Lisboa), where no troglobiont species have been found so far, the superficial vegetation has been totally replaced by buildings, inducing changes of water and nutrient flow in the deep karst.

Another issue threat to the obligate hypogean biodiversity is the mass speleological tourism, which induces deep changes on morphological cave structure, on water chemistry and movement, composition and temperature of air masses, and promotes the introduction of artificial light and exotic species, besides the vandalism present in caves both open or not to public visit (Reboleira, 2007).

The ecological protection in karst areas is clearly inefficient. There is increase of use of pesticides and fertilizers in agriculture, the continued proliferation of quarries and the change in vegetation cover. There is no specific legislation and no effective control on the visits of most cavities, with the exception of Algar do Pena (Estremenho), there is no concerted concern for the conservation of subterranean biodiversity, even in caves protected by law like Gruta do Zambujal (Arrábida), Gruta da Assafora (Sintra) and Gruta do Almonda (Estremenho).

In the Azores the main problem on the conservation of subterranean fauna is related to the destruction of native forest for pasture development, which causes clay filling of underground spaces and a limitation of lava-tubes available for the obligate hypogean fauna. This can easily lead to the extinction of locally endemic populations often limited to a single cave, with the corresponding loss of this biological endemic heritage. Troglobiont planthoppers populations, which depend on the presence of tree roots for survival inside the caves, are especially affected. Currently the 267 caves known in the Azores (Pereira et al. in press) are being evaluated for their conservation value (see Borges et al., 2008). A working group (GESPEA) was created by the Azores Government Decree nr. $149 / 98$ of $25^{\text {th }}$ July to study this diversified natural, cultural, scientific and aesthetic heritage, which must be preserved with special measures. Since then four caves were classified as Regional Natural Monuments (Algar do Carvão in Terceira, Furna do Enxofre in Graciosa, Gruta das Torres in Pico, Gruta do Carvão in São Miguel) and have special regulations concerning their use as show caves.

Based on the work of GESPEA, all the Azorean caves are now classified in four levels of priority $(A, B, C$, $\mathrm{D})$, the level $\mathrm{A}$ including 30 caves in six islands that will be subject to special conservation actions. The 
importance of these caves is based on their biological diversity and geological value, a show cave index and an integrity index (see also Gabriel et al. 2008 for an application example with bryophytes).

In the island of Madeira only 13 caves are known, the largest cave (Gruta de São Vicente) was drastically changed and rebuilt in the 1990's to be transformed in a show cave with the financial support of EC through the Regional Government, with very important changes that eliminated the specialized cave fauna. Gruta dos Cardais, also in São Vicente, is now used for storing animals and junk, and Grutas de Cavalum in Machico is full of litter due to uncontrolled visits.

\section{CONCLUDING REMARKS}

The troglobiont and stygobiont species listed represent a small proportion of the overall rich fauna of the studied regions. In general, all species are local endemisms. In addition, most of the species occur in single locations or there is a high degree of isolation between different populations. Apparently, the vast majority of troglobionts and stygobionts fulfill the IUCN criteria for endangered species. For instance, in the United States of America, 50\% of the national species listed as vulnerable or imperiled, as defined by Nature Conservancy, are cave obligated species (Culver et al., 2000).

It is therefore fundamental to carry out more field work, discovering new caves and describing new species that remain to be found, updating the distribution of species, assessing the abundance of species and evaluating their conservation status according to the latest IUCN criteria (IUCN Standards and Petitions Subcommittee, 2010).

Cave fauna can also be viewed as a unique biological laboratory where evolutionary and ecological processes can be studied.

In conclusion, additional efforts should be undertaken in order to:

a) improve the cave and MSS biodiversity knowledge;

b) determine what triggers the evolution of speciesrich genera (e.g. Trechus beetles). This will help in the identification of evolutionary significant units for conservation;

c) investigate the effects of exotic species that are spreading in cave entrances and may be putative threats to the cave obligate species also occurring near entrances (e.g. in Azores);

d) collaborate on the conservation management of surface habitats, putting together high quality distribution data of cave species with information on surface land-uses through GIS projects and propose according conservation management measures;

e) select crucial areas to the conservation of Portuguese obligate cave fauna. The restricted distribution of most species would imply that most caves are unique and largely irreplaceable. A multiplecriteria index incorporating diversity- and rarity-based indices could help in selecting priorities;

f) provide ecotoxicological information on the sensitiveness of subterranean species to several anthropogenic pollutants, contributing to estimate their impacts on these particular ecosystems.

The preservation of the biodiversity of the subterranean environment is critical if the 2010 Biodiversity Target - Convention of Biological Diversity, United Nations Environmental Program (CBD, 2007) is to be met, which will require a serious and prompt commitment from land management agents and politicians. This is already occurring in the Azores, but similar efforts are absent in mainland Portugal and Madeira.

\section{ACKNOWLEDGEMENTS}

We would like to express our gratitude to F.T. Regala and L.F. Mendes for kindly providing some bibliographic support and E. Mendonça for providing photos. We are grateful to A. Sendra, J.A. Zaragoza, L. Mendes and T. Pipan for some explanatory comments, to Xavier Riesco for his revision of the English and to the editor of the IJS and two referees for their useful comments. PAVB worked on this manuscript under the FCT project PTDC/AMB/70801/2006 Understanding Underground Biodiversity: Studies of Azorean Lava Tubes. ARMS worked on this manuscript under the Centro de Biologia Ambiental support. The Portuguese Foundation for Science and Technology financed ASPSR by the mean of PhD grant (SFRH/ $\mathrm{BD} / 45744 / 2008)$.

\section{REFERENCES}

Afonso O., 1978 - Une nouvelle espèce d'Isopode troglobie du Portugal. Publ. Inst. Zool. "Dr. Augusto Nobre", 61: 11-23.

Afonso O., 1979 - Un Proasellus (Crust. Isopoda) nouveau du Portugal. An. Fac. Ciênc. Univ. Porto, 61(1-4): 91104.

Afonso O., 1982a - Description d'une nouvelle espèce de Proasellus (Crust. Isopoda) du Portugal et des considérations sur la phylogénie de son genre. Publ. Inst. Zool. "Dr. Augusto Nobre", 163: 1-15.

Afonso O., 1982b - Sur un Proasellus (Crustacea, Isopoda, Asellidae) cavernicole nouveau du Portugal. Publ. Inst. Zool. "Dr. Augusto Nobre", 166: 1-10.

Afonso O., 1982c - Un nouvel asellide cavernicole du Portugal: Proasellus mateusorum sp. n. (Crustacea, Isopoda, Asellota). Publ. Inst. Zool. "Dr. Augusto Nobre", 168: 1-10.

Afonso O., 1983 - Un aselle phreatique nouveau du bassin du Mondego (Portugal) et des considerations sur les Asellides Portugais (Crust., Isopoda, Asellidae). Publ. Inst. Zool. "Dr. Augusto Nobre", 178: 1-14.

Afonso O., 1984a - Un nouveau Synasellus (Crust., Isopoda, Asellidae) de la nappe phréatique littorale au sud du Douro. Publ. Inst. Zool. "Dr. Augusto Nobre", 185: $1-12$.

Afonso O., 1984b - Bragasellus incurvatus sp. $n$. (Crustacea, Isopoda, Asellidae) nouvelle espèce hypogée $d u$ bassin $d u$ Douro. Publ. Inst. Zool. "Dr. Augusto Nobre", 187: 1-9.

Afonso O., 1985 - Un asellide nouveau (Crustacea, Isopoda) de la nappe phréatique du Douro: Synasellus intermedius sp. n. Publ. Inst. Zool. "Dr. Augusto Nobre", 188: $1-8$. 
Afonso O., 1987a - Un nouveau phréatobie du nord du Portugal, Synasellus bragai sp. n. (Crustacea, Isopoda, Asellidae). Algar, 1: 39-46.

Afonso O., 1987b - Contribuition pour la connaissance des rapports entre la qualité de l'eau phréatique et les communautés d'Asellides (Crustacea, Isopoda, Asellota). Publ. Inst. Zool. "Dr. Augusto Nobre", 198: $1-61$.

Afonso O., 1988 - Isopoda Asellidae e Amphipoda da Gruta da Assafora (Portugal) - descrição de Proasellus assaforensis sp. n. Algar, 2: 43-50.

Afonso O., 1992 - Aselídeos (Crustacea, Isopoda) nas águas subterrâneas portuguesas. Aspectos taxonómicos, bio-geográficos e ecológicos. Algar, 3: 49-56.

Afonso O., 1996 - Isopodes (Crustacea, Asellidae) stygobies du Nord du Portugal. Description de trois nouvelles especes. Publ. Inst. Zool. "Dr. Augusto Nobre", 235: 1-14.

Amorim I.R., 2005 - Colonization and diversification on oceanic islands: forest Tarphius and cave dwelling Trechus beetles of the Azores. Ph.D. dissertation, Department of Ecology and Evolutionary Biology, University of California, Los Angeles, 282 pp.

Ávila S., Madeira P., Zazo C., Krohe A., Kirbyf A., Marques da Silva C., Cachão M. \& Frias Martins A., 2008 Palaeoecology of the Pleistocene (MIS 5.5) outcrops of Santa Maria Island (Azores) in a complex oceanic tectonic setting. Palaeogeogr. Palaeoclimat. Palaeoecol., 274: 18-33.

Bellés X., 1987 - Fauna cavernícola i intersticial de la Península Ibérica $i$ les Mles Balears. Con. Sup. Inv. Cien., Ed. Moll, Mallorca, 207 pp.

Bivort B.L. \& Giribet G., 2004 - A new genus of cyphophthalmid from the Iberian Peninsula. Invert Syst., 18: 7-52.

Borges P.A.V., 1993 - First records for the mesocavernous shallow stratum (M.S.S.) from the Azores. Mém Biospéol. 20: 49-54.

Borges P.A.V. \& Oromí P., 1991 - Cave-dwelling ground beetles of the Azores (Col., Carabidae). Mém Biospéol., 18: 185-191.

Borges P.A.V. \& Oromí P., 1994 - Encyclopaedia Biospeleologica. Tome I. Sociétè de Biospéologie, Moulis. The Azores: 605-610.

Borges P.A.V., Serrano A.R.M. \& Amorim I.R., 2004 - New species of cave-dwelling beetles (Coleoptera: Carabidae: Trechinae) from the Azores. J. Nat. Hist., 38: 13031313.

Borges P.A.V., Oromí P., Serrano A.R.M., Amorim I.R. \& Pereira P., 2007 - Biodiversity patterns of cavernicolous ground-beetles and their conservation status in the Azores, with the description of a new species: Trechus isabelae n. sp. (Coleoptera: Carabidae: Trechinae). Zootaxa, 1478: 21-31.

Borges P.A.V., Pereira F. \& Constância J.P., 2008 Indicators of conservation value of Azorean caves based on its arthropod fauna. Proceedings of the X, XI and XII International Symposia on Vulcanospeleology: 109-113.
Borges P.A.V. \& Wunderlich J. 2008 - Spider biodiversity patterns and their conservation in the Azorean archipelago, with description of new taxa. Syst Biodiv., 6: 249-282.

Borges P.A.V., Gabriel R., Arroz A., Costa A., Cunha R., Silva L., Mendonça E., Reis F., Martins A.F. \& Cardoso P., in press - The Azorean Biodiversity Portal: a regional model internet database on biodiversity data sharing. Syst Biodiv., 8, in press.

Braga J.M., 1942a - Mancasellus mariae, a new blind Isopod inhabiting subterranean waters in Portugal. Mem. Est. Mus. Zool. Univ. Coimbra, 130: 1-11.

Braga J.M., 1942b - Un Isopode nouveau du Portugal Stenasellus nobrei $n$. sp. Publ. Inst. Zool. "Dr. Augusto Nobre", 10: 1-11.

Braga J.M., 1943 - Description de l'Asellus seabrai, isopode aveugle noveau des eaux soubterraines $d u$ Portugal. Publ. Inst. Zool. "Dr. Augusto Nobre", 14: 1-17.

Braga J.M., 1944 - Note sur un genre d'Asellides nouveau du Portugal (Synasellus n. gen.) et description d'une sous-espèce nouvelle de ce genre. Publ. Inst. Zool. "Dr. Augusto Nobre", 17: 1-11.

Braga J.M., 1945 - Un nouvelle Aselle cavernicole du Portugal. Publ. Inst. Zool. "Dr. Augusto Nobre", 24: $1-15$.

Braga J.M., 1946 - Quelques Asellides nouveaux du Portugal. Synasellus fragilis n. sp., Asellus coxalis ibericus n. subsp., Asellus conimbricensis n. sp. Publ. Inst. Zool. "Dr. Augusto Nobre”, 29: 1-15.

Braga J.M., 1949 - Un Bathynellidae (Crust. Syncarida) du Portugal (Parabathynella lusitanica n. sp.). Publ. Inst. Zool. "Dr. Augusto Nobre", 40: 1-15.

Braga J.M., 1958 - Un Asellus remarquable des eaux souterraines du Portugal (Asellus pauloae n. sp.). Publ. Inst. Zool. "Dr. Augusto Nobre", 61: 1-15.

Braga J.M., 1960a - Synasellus albicastrensis un nouveau asellide troglobie du Portugal. An. Fac. Ciênc. Univ. Porto, 43: 1-15.

Braga J.M., 1960b - Sur une Parabathynella (Crust. Syncarida) nouvelle du Portugal. Publ. Inst. Zool. "Dr. Augusto Nobre", 75: 9-22.

Braga J.M., 1962 - Sur la distribuition géographique des Stenasellus de la Péninsule Ibérique et description d'une espèce nouvelle de ce genre. An. Fac. Ciênc. Univ. Porto, 84: 9-28.

Braga J.M., 1964 - Contribution à la faune d'asellides du Portugal Asellus frontellum sp. n. Publ. Inst. Zool. "Dr. Augusto Nobre", 91: 9-18.

Braga J.M., 1967 - Trois Synasellus (Crust, Isopoda) nouveaux $d u$ Portugal Synasellus serranus $s p$. $n$. Synasellus nobrei sp. n. Synasellus minutus sp. n. An. Fac. Ciênc. Univ. Porto, 50(3-4): 301-324.

Braga J.M., 1968 - Sur un Asellide psammique nouveau du Portugal. Publ. Inst. Zool. "Dr. Augusto Nobre”, 102: 1-21.

Bréhier F. \& Jaume D., 2009 - A new species of Pseudoniphargus (Crustacea, Amphipoda, Melitidae) from an anchialine cave on the French Mediterranean coast. Zoosystema, 31(1): 17-32. 
Brilha J., Andrade C., Azerêdo A., Barriga F.J.A.S., Cachão M., Couto H., Cunha P.P., Crispim J.A., Dantas P., Duarte L.V., Freitas M.C., Granja H.M., Henriques M.H., Henriques P., Lopes L., Madeira J., Matos J.M.X., Noronha F., Pais J., Piçarra J., Ramalho M.M., Relvas J.M.R.S., Ribeiro A., Santos A., Santos V.F. \& Terrinha P., 2005 - Definition of the Portuguese frameworks with international relevance as an input for the European geological heritage characterisation. Episodes, 28(3): 177-186.

Camacho A.I., 2003a - Four new species of groundwater crustaceans (Syncarida, Bathynellacea, Parabathynellidae) endemic to the Iberian Peninsula. J. Nat. Hist., 37: 2885-2907.

Camacho A.I., 2003b - Historical biogeography of Hexabathynella, a cosmopolitan genus of groundwater Syncarida (Crustacea, Bathynellacea, Parabathynellidae). Biol. J. Linn. Soc., 78: 457-466.

Cardoso P. \& Scharff N., 2009 - First record of the spider family Symphytognathidae in Europe and description of Anapistula ataecina sp. n. (Araneae). Zootaxa, 2246: 45-57.

Christiansen, K. 2005 - Morphological Adaptations. In: Culver D.C. \& White W. (Eds.) Encyclopedia of Caves. Elsevier Academic Press USA: 386-397.

CBD [Internet]. 2007 - Conference of the Parties Decisions. Convention on Biological Diversity. [Cited 09 March 2010]. Available from: http://www.biodiv.org/ decisions.

Culver D.C., 2001 - Subterranean ecosystems. In: Levin S.A. (Ed.), Encyclopaedia of Biodiversity, Volume 5. Academic Press: 527-540.

Culver D.C., Master L.L., Christman M.C. \& Hobbs III H.H., 2000 - Obligate cave fauna of the 48 contiguous United States. Cons. Biol., 14: 386-401.

Culver D.C. \& Pipan T., 2009 - Biology of caves and other subterranean habitats. Oxford University Press, Oxford: 256 p.

Dalens H., 1984 - Isopodes terrestres rencontrés dans les cavités volcaniques de l'iles de Tenerife. Trav Lab. Ecobiol. Arthr. Edaph. Toulouse, 5(1): 12-19.

Eason E.H. \& Ashmole N.P., 1992 - Indigenous centipedes from caves and lava flows on the Azores. Zool. J. Linn. Soc., 105: 407-429.

Eiras J., 1974 - Un nouveau Synasellus (Crustacea, Isopoda) du Portugal. Publicações do Instituto de Zoologia "Augusto Nobre", 124: 9-21.

Erber D., 1990 - Thalassophilus pieperi n. sp., a new cavernicolous carabid beetle from Madeira. Bocagiana, 140: $1-12$.

Frade F., 1938 - Un Asellus (Isopode) nouveau des eaux souterraines du Portugal. Bol. Soc. Port. Ciênc. Nat., 7(5): 17-24.

Gabriel R., Pereira F., Borges P.A.V. \& Constância J.P., 2008 - Indicators of Conservation Value of Azorean Caves Based on its Bryophyte Flora at Cave Entrances. Proceedings of the X, XI and XII International Symposia on Vulcanospeleology: 114-118.

Gama M.M. 1962 - Collemboles des grottes du Portugal. Voyage au Portugal du Dr. K. Lindberg. Résultats zoologiques $n^{\circ}$ 5. Bol. Soc. Port. Ciênc. Nat., 9(2): 100108.
Gama M.M., 1988 - Systématique évolutive des Pseudosinella .XIV. Deux espèces nouvelles provenant des Açores (Ins., Collembola). Rev Suisse Zool., 95: 607-611.

Gama M.M. \& Afonso O., 1994 - Portugal. In: Juberthie C. \& Decu V. (Eds.), Encyclopaedia Biospeologica, tome I. Sociétè de Biospéologie, Moulis, France: 771-778.

Giani N., Sambugar B., Rodriguez P. \& MartinezAnsemil E., 2001 - Oligochaetes in southern European groundwater: new records and an overview. Hydrobiologia, 463: 65-74.

Hoch H., 1991 - Cave-dwelling Cixiidae (Homoptera, Fulgoroidea) from the Azores. Bocagiana. 149: 1-9.

Howarth F.G., 1983 - Ecology of cave arthropods. An. Rev. Entomol., 28: 365-389.

Hrabe S., 1963 - On Rhyacodrilus lindbergi n. sp., a new cavernicolous species of the family Tubificidae (Oligochaeta) from Portugal. Bol. Soc. Port. Ciên. Nat., 10(2): 52-56.

IUCN Standards and Petitions Subcommittee, 2010 Guidelines for Using the IUCN Red List Categories and Criteria. Version 8.1. Prepared by the Standards and Petitions Subcommittee in March 2010: 85 p.

Jeannel R., 1941 - Premières explorations des grottes du Portugal par M.A. de B. Machado, Coléoptères. Publ. Inst. Zool. "Dr. Augusto Nobre, 4: 5-15.

Juberthie C., Delay B. \& Bouillon M., 1980a - Sur l'existence d'un milieu souterrain superficiel en zone non calcaire. C. R. Acad. Sci. Paris., 290: 49-52.

Juberthie C., Delay B. \& Bouillon M., 1980b - Extension du milieu souterrain en zone non calcaire: description d'un nouveau milieu et de son peuplement par les coleóptères troglobies. Mém Biospéol., 7: 19-52.

Lescher-Moutoué F., 1981 - Cyclopidae des eaux souterraines du Portugal et de l'île de Majorque (Crustacea, Copepoda). Bul. Zool. Mus. Amsterdam., 8: 65-67.

Machado A., 1988 - Two new cavernicolous species of the genus Trechus Clairv. from the Azores (Coleoptera, Carabidae). Bocagiana, 119: 1-8.

Machado A.B., 1946 - Contribuição para o conhecimiento dos miriápodes de Portugal. Brotéria, 15: 5-37.

Machado A.B. \& Machado B.B., 1948 - Inventário das cavernas calcárias de Portugal. Bol. Soc. Port. Ciênc. Nat., 13: 444-473.

Magniez G., 1966 - Geographic distribution and validity of the troglobe species Asellus lusitanicus Frade (Asellote Crustacean). Int. J. Speleol., 2(4): 315-317.

Magniez G., 1999 - Isopodes Aselloides stygobies d'Espagne, IV-Stenasellidae: taxonomie, histoire evolutive et biogeographie. Beaufortia, 49 (11): 115139.

Mahnert V., 1990 - Deux nouvelles espèces du genre Pseudoblothrus Beier, 1931 (Pseudoscorpiones, Syarinidae) des Açores (Portugal). Vieraea, 18: 167170.

Mateus A. \& Mateus E., 1958 - Un nouveau genre et une nouvelle espèce d'Amphipode troglobie du Portugal. Mem. Est. Mus. Zool. Univ. Coimbra, 252: 1-10.

Mateus A. \& Mateus E., 1978 - Amphipoda hypogés du Portugal. Publ. Inst. Zool. "Dr. Augusto Nobre”, 142: 11-26. 
Myers N., Mittermeler R.A., Mittermeler C.G., Fonseca G.A.B. \& Kents J., 2000 - Biodiversity hotspots for conservation priorities. Nature, 403: 853-858.

Noodt W. \& Galhano M.H., 1969 - Studien an Crustacea Subterranea (Isopoda, Syncarida, Copepoda) aus dem Norden Portugals. Publ. Inst. Zool. "Dr. Auguste Nobre", 107: 9-75.

Notenboom J., 1987 - Lusitanian species of the amphipod. Pseudoniphargus Chevreux, 1901 with a key to all Iberian species. Bijdragen tot de Dierkunde, 57(2): 191-206.

Notenboom J., 1990 - Introduction to Iberian groundwater amphipods. Limnetica, 6: 165-176.

Nunes E., 2005 - Os Tubos de Lava de Machico (Tha da Madeira, Portugal): Biodiversidade e Conservação. BSc Thesis, Dpto. de Biologia, Universidade da Madeira: 50 p.

Oromí P., 1992 - La Fauna Subterránea en las Islas Macaronésicas. Actas do $3^{\circ}$ Congresso Nacional de Espeleologia e do $1^{\circ}$ Encontro Internacional de Vulcanoespeleologia das Ilhas Atlânticas: 193-205.

Oromí P., Martín J.L., Ashmole, N.P. \& Ashmole M.J., 1990 - A preliminary report on the cavernicolous fauna of the Azores. Mém. Biospéol., 17: 97-105.

Oromí P. \& Borges P.A.V., 1991 - New Trechodinae and Trechinae from the Azores (Col.: Carabidae). Bocagiana, 152: 1-11.

Pereira F., Borges P.A.V., Costa M.P., Constância J.P., Nunes J.C., Barcelos P. Braga T., Gabriel R., Amorim I.R., in press - Catálogo das cavidades vulcânicas dos Açores (grutas lávicas, algares e grutas de erosão marinha). Direcção Regional do Ambiente, Horta.

Reboleira A.S.P.S., 2007 - Coleópteros (Insecta: Coleoptera) cavernicolas do Maciço Calcáreo Estremenho: uma abordagem à sua biodiversidade. MSc dissertation, Departamento de Biologia, Universidade de Aveiro, Portugal: 74 pp.

Reboleira A.S.P.S., Gonçalves F. \& Serrano A.R.M., 2009 - Two new species of cave dwelling Trechus Clairville, 1806 of the fulvus-group (Coleoptera, Carabidae, Trechinae) from Portugal. Deuts. Entomol. Zeits., 56(1): 101-107.

Ribera C., 1988 - La familia Leptonetidae (Arachnida, Araneae) in la Península Ibérica. XI Europäisches Arachnologisches Colloquium. Tech Univ Berli Insekt, Konchuaikokai., 26: 14-18.

Ribera C. 1993 - Dysdera caeca n. sp. y Harpactea stalitoides n. sp. (Araneae), dos nuevas especies cavernicolas de Marruecos y Portugal. Rev Arachnol., 10(1): 1-7.

Rosenzweig M.L., 1995 - Species diversity in space and time. Cambridge University Press, Cambridge: 436 p.

Salgado J.M., Blas M. \& Fresneda J., 2008 - Coleoptera Cholevidae. In "Fauna Ibérica", vol. 31. Ramos, M.A. (Ed.), Museo Nacional de Ciencias Naturales, CSIC, Madrid: 799 p.
Sánchez E.L., 1990 - A new species of Pseudoniphargus (Crustacea, Amphipoda) from subterranean waters in Tenerife (Canary Islands). Hidrobiología, 196: 51-63.

Serrano A.R.M., 1993 - Medon vicentensis n. sp., a new species of eyeless rovebeetle (Coleoptera: Staphylinidae: Paederinae) from a cave in the island of Madeira. Bocagiana, 165: 1-7.

Serrano A.R.M. \& Aguiar CAS., 2008a - A new species of the genus Geocharis Ehlers, 1883 and some faunistic data on endogenan carabids from Portugal. Rev. Suisse Zool., 115(4): 779-788.

Serrano A.R.M. \& Aguiar CAS., 2008b - Two new species of Thyphlocaris Dieck, 1869 (Coleoptera, Carabidae) from Portugal: description and notes on the related species. Graellsia, 64(2): 281-293.

Stock J.H., 1980 - Regression model evolution as exemplified by the genus Pseudoniphargus (Amphipoda). Bijdr. Dierk., 50(1): 105-144.

Stock J.H., 1992 - A new species of Ingolfiella (Crustacea, Amphipoda, Ingolfiellidae) from mixohaline waters in Madeira. Bocagiana, 159: 1-11.

Stock J.H. \& Abreu A.D., 1992 - Three new species of Pseudoniphargus (Crustacea: Amphipoda) from the Madeira Archipelago. Bol. Mus. Mun. Funchal., 44: 131-155.

Strinati P. \& Condé B., 1995 - Grottes et Palpigrades de Madère. Mém. Biospéol., 22: 161-168.

Sket B., 1999 - The nature of biodiversity in hypogean waters and how it is endangered. Biodiv. Cons., 8: 1319-1338.

Sket B., 2008 - Can we agree on an ecological classification of subterranean animals? J. Nat. Hist., 42(21-22): 1549-1563.

Vandel A., 1945 - Crustacés Isopodes terrestres (Oniscoïdea) épigés et cavernicoles du Portugal. Étude des recoltes de M. A. de Barros Machado. An. Fac. Ciênc. Porto., 30: 138-427.

Watson J., Hamilton-Smith E., Gillieson D., Kiernan K., 1997 - Guidelines for Cave and Karst Protection: IUCN World Commission on Protected Areas. Prepared by the WCPA Working Group on Cave and Karst Protection. IUCN Protected Area Programme Series: 53 pp.

Wunderlich J. 1992 - Die Spinnen-Fauna der Makaronesischen Inseln. Taxonomie, Ökologie, Biogeographie und Evolution. Beitr. Araneol., 1: 1-619.

Wunderlich J., 1995 - Zur Ökologie, Biogeographie, Evolution und Taxonomie einiger Spinnen der Makaronesischen Inseln. Beitr. Araneol., 4: 385-439.

Zaragoza J.A., Aguín-Pombo D. \& Nunes E., 2004 Paraliochthonius cavalensis, nueva espécie cavernícola de Madeira (Arachnida, Pseudoscorpiones, Chthoniidae). Rer. Ibér. Aracnol., 9: 343-351.

Zaragoza J.A., 2007 - Catálogo de los Pseudoescorpiones de la Península Ibérica e Islas Baleares (Arachnida: Pseudoscorpiones). Rer. Ibér. Aracnol., 13: 3-91. 


\section{APPENDIX}

Table 1. Troglobionts of mainland Portugal

\begin{tabular}{|l|l|l|l|}
\hline Order & Family & Species & Karst area \\
\hline Pseudoescorpiones & Neobisidae & Roncocreagris blothroides (Beier), 1962 & Sicó \\
\hline & & Roncocreagris cavernicola (Vachon), 1946 & Sicó \\
\hline Araneae & Dysderidae & Harpactea stalitoides Ribera, 1993 & Algarve \\
\hline & Sironidae & Iberosiro dyctilus Bivort \& Giribet, 2007 & Montejunto \\
\hline & Leptonetidae & Teloleptoneta synthetica (Machado, 1951) & Arrábida, Adiça, Algarve \\
\hline & Nesticidae & Nesticus lusitanicus Fage, 1931 & Estremenho \\
\hline & Symphytognathidae & Anapistula ataecina Cardoso \& Scharff, 2009 & Arrábida \\
\hline Lithobiomorpha & Lithobidae & Lithobius dimorphus Machado, 1946 & Algarve \\
\hline & Porcelionidae & Porcellio cavernicolous Vandel, 1945 & Sicó \\
\hline & Trichoniscidae & Trichoniscoides broteroi Vandel, 1945 & Sicó \\
\hline & & Trichoniscoides subterraneus Vandel, 1945 & Estremenho \\
\hline & & Trichoniscoides meridionalis Vandel, 1945 & Estremenho \\
\hline & & Trichoniscoides ouremensis Vandel, 1945 & Estremenho \\
\hline Entomobryomorpha & Onychiuridae & Trichoniscoides machadoi subterraneus Vandel, 1945 & Algarve \\
\hline Coleoptera & Carabidae & Troglarmadillidium machadoi Vandel, 1945 & Algarve \\
\hline & & Onychiurus confugiens Gama, 1962 & Estremenho \\
\hline & & Trechus machadoi Jeannel, 1942 & Estremenho \\
\hline & Leiodidae & Trechus gamae Reboleira \& Serrano, 2009 lunai Reboleira \& Serrano, 2009 & Estremenho \\
\hline & & Speonemadus angusticollis (Kraatz, 1870) & Estremenho \\
\hline
\end{tabular}


Table 2. Stygobionts of mainland Portugal

\begin{tabular}{|c|c|c|c|}
\hline Order & Family & Species & Area \\
\hline Tubificida & Tubificidae & Rhyacodrilus lindbergi Hrabe, 1962 & Estremenho, France \\
\hline \multirow[t]{8}{*}{ Syncarida } & Parabathynellidae & Hexabathynella minuta (Noodt \& Galhano, 1969) & Douro \\
\hline & & Iberobathynella lusitanica (Braga, 1949) & Leça da Palmeira \\
\hline & & Iberobathynella barcelensis (Noodt \& Galhano, 1969) & Barcelos \\
\hline & & Iberobathynella valbonensis (Galhano, 1970) & Gondomar, Spain \\
\hline & & Iberobathynella gracilipes (Braga, 1960) & Idanha-a-Nova \\
\hline & & Iberobathynella cavadoensis (Noodt \& Galhano, 1969) & Cávado, Spain \\
\hline & & Iberobathynella serbani Camacho, 2003 & Ponte de Lima \\
\hline & & Iberobathynella pedroi Camacho, 2003 & Mondego, Coimbra \\
\hline \multirow[t]{6}{*}{ Amphipoda } & Melitidae & Pseudoniphargus mateusorum Stock, 1980 & Arrábida \\
\hline & & Pseudoniphargus longispinum Stock, 1980 & Portugal \\
\hline & & Pseudoniphargus callaicus Notenboom, 1987 & North Atlantic and Spain \\
\hline & Niphargidae & Haploginglymus bragai Mateus \& Mateus 1958 & Leça da Palmeira, Spain \\
\hline & Hadziidae & Metahadzia tavaresi (Mateus \& Mateus, 1972) & Algarve \\
\hline & Bogidiellidae & Bogidiella helenae Mateus \& Maciel, 1967 & Foz do Douro \\
\hline \multirow[t]{37}{*}{ Isopoda } & Asellidae & Bragasellus seabrai (Braga, 1943) & Matosinhos \\
\hline & & Bragasellus conimbricensis (Braga, 1946) & Coimbra \\
\hline & & Bragasellus frontellum (Braga, 1964) & Minho \\
\hline & & Bragasellus incurvatus Afonso, 1984 & Douro \\
\hline & & Bragasellus pauloae (Braga, 1958) & Idanha-a-Nova \\
\hline & & Proasellus arthrodilus (Braga, 1945) & Sicó \\
\hline & & Proasellus assaforensis Afonso, 1988 & Sintra \\
\hline & & Proasellus exiguus Afonso, 1983 & Viseu \\
\hline & & Proasellus lusitanicus (Frade, 1938) & Estremenho \\
\hline & & Proasellus mateusorum Afonso, 1982 & Vendas Novas \\
\hline & & Proasellus nobrei Braga, 1942 & Foz do Douro \\
\hline & & Proasellus rectus Afonso, 1982 & Évora \\
\hline & & Proasellus rectangulatus Afonso, 1982 & Montemor-o-Novo \\
\hline & & Proasellus spinipes Afonso, 1979 & Estremenho \\
\hline & & Psammasellus capitatus Braga, 1968 & Douro \\
\hline & & Synasellus albicastrensis Braga, 1960 & Castelo Branco \\
\hline & & Synasellus barcelensis Noodt \& Galhano, 1969 & Cávado \\
\hline & & Synasellus bragai Afonso, 1987 & Minho \\
\hline & & Synasellus brigantinus Braga, 1959 & Bragança \\
\hline & & Synasellus capitatus (Braga, 1968) & Porto \\
\hline & & Synasellus dissimilis Afonso, 1987 & Serzedelo \\
\hline & & Synasellus exiguus Braga, 1944 & Douro \\
\hline & & Synaselus favaiensis Eiras, 1974 & Douro \\
\hline & & Synasellus flaviensis Afonso, 1996 & Minho \\
\hline & & Synasellus fragilis (Braga, 1946) & Gondomar \\
\hline & & Synasellus henrii Afonso, 1987 & Póvoa de Lanhoso \\
\hline & & Synasellus insignis Afonso, 1984 & Vila Nova de Gaia \\
\hline & & Synasellus intermedius Afonso, 1985 & Douro \\
\hline & & Synasellus lafonensis Braga, 1959 & Vouga \\
\hline & & Synasellus longicauda (Braga, 1959) & Douro \\
\hline & & Synasellus longicornis Afonso, 1978 & Interior \\
\hline & & Synasellus mariae (Braga, 1942) & Leça da Palmeira \\
\hline & & Synasellus mateusi Braga, 1954 & Chaves \\
\hline & & Synasellus meirelesi Braga, 1959 & Algarve \\
\hline & & Synasellus minutus Braga, 1959 & Curia \\
\hline & & Synasellus nobrei Braga, 1967 & Douro \\
\hline & & Synasellus pireslimai Braga, 1959 & Vouga \\
\hline
\end{tabular}


(Table 2, continued)

\begin{tabular}{|l|l|l|l|}
\hline Order & Family & Species & Area \\
\hline Isopoda & Asellidae & Synasellus pombalensis Afonso, 1987 & Pombal \\
\hline & & Synasellus robusticornis Afonso, 1987 & Santa Comba Dão \\
\hline & & Synasellus serranus Braga, 1967 & Viana do Castelo \\
\hline & & Synasellus tirsensis Afonso, 1987 & Rio Varziela \\
\hline & & Synasellus transmontanus Braga, 1954 & Bragança \\
\hline & Synasellus valpacensis Afonso, 1996 & Valpaço \\
\hline & Synasellus vidaguensis Afonso, 1996 & Vidago \\
\hline & & Synasellus vilacondensis Afonso, 1987 & Vila do Conde \\
\hline & & Stenasellus galhanoae Braga, 1962 & Algarve \\
\hline & & Stenasellus virei nobrei Braga, 1942 & Douro, Guarda \\
\hline
\end{tabular}

Table 3. Troglobionts of Madeira Archipelago

\begin{tabular}{|l|l|l|l|}
\hline Order & Family & Species & Islands \\
\hline Palpigradi & Eukoeneniidae & Eukoenenia madeirae Strinati \& Condé, 1995 & Madeira \\
\hline Pseudoscorpiones & Chthoniidae & Paraliochthonius cavalensis Zaragoza, 2004 & Madeira \\
\hline Araneae & Linyphiidae & Centromerus sexoculatus Wunderlich, 1992 & Madeira \\
\hline & & Centromerus anoculus Wunderlich, 1995 & Madeira \\
\hline Isopoda & Trichoniscidae & Trichoniscus bassoti Vandel, 1960 & Madeira \\
\hline Coleoptera & Carabidae & Thalassophilus pieperi Erber, 1990 & Madeira \\
\hline & & Thalassophilus coecus Jeannel, 1938 & Madeira \\
\hline & Staphylinidae & Medon vicentensis Serrano, 1993 & Madeira \\
\hline
\end{tabular}

Table 4. Stygobionts of Madeira Archipelago

\begin{tabular}{|l|l|l|l|}
\hline Order & Family & Species & Islands \\
\hline Amphipoda & Melitidae & Pseudoniphargus portosancti Stock \& Abreu, 1992 & Porto Santo \\
\hline & & Pseudoniphargus macrurus Stock \& Abreu, 1992 & Madeira \\
\hline & & Pseudoniphargus litoralis Stock \& Abreu, 1992 & Madeira \\
\hline & Ingolfiellidae & Ingolfiella ungiculata Stock, 1992 & Madeira \\
\hline
\end{tabular}

Table 5. Troglobionts of Azores Archipelago

\begin{tabular}{|l|l|l|l|}
\hline Order & Family & Species & Islands \\
\hline Pseudoescorpiones & Syarinidae & Pseudoblothrus vulcanus Mahnert, 1990 & Terceira \\
\hline & & Pseudoblothrus oromii Mahnert, 1990 & São Jorge \\
\hline Araneae & Theridiidae & Rugathodes pico (Merrett \& Ashmole, 1989) & Pico, Faial \\
\hline & Linyphiidae & Turinyphia cavernicola Wunderlich, 2005 & Terceira \\
\hline Lithobiomorpha & Lithobidae & Lithobius obscurus azoreae Eason \& Ashmole, 1992 & Faial, Pico, Graciosa, Terceira \\
\hline Homoptera & Cixidae & Cixius azopicavus Hoch, 1991 & Pico \\
\hline & & Cixius cavazoricus Hoch, 1991 & Faial \\
\hline Coleoptera & Carabidae & Thalassophilus azoricus Oromí \& Borges, 1991 & S. Miguel \\
\hline & & Trechus terceiranus Machado, 1988 & Terceira \\
\hline & & Trechus picoensis Machado, 1988 & Pico \\
\hline & & Trechus pereirai Borges, Serrano \& Amorim, 2004 & Pico \\
\hline & Trechus montanheirorum Oromí \& Borges, 1991 & Pico \\
\hline & & Trechus jorgensis Oromí \& Borges, 1991 & S. Jorge \\
\hline & Trechus oromii Borges, Serrano \& Amorim, 2004 & Faial \\
\hline & & Trechus isabelae Borges \& Serrano, 2007 & S. Jorge \\
\hline
\end{tabular}

Table 6. Stygobiont of Azores

\begin{tabular}{|l|l|l|l|}
\hline Order & Family & Species & Islands \\
\hline Amphipoda & Melitidae & Pseudoniphargus brevipedunculatus Stock, 1990 & Faial \\
\hline
\end{tabular}

